\title{
Collective Bargaining Rights under the Workplace Relations Act: The Boeing Dispute
}

\section{Jenny Whittard, Mark Bray, Roslyn Larkin, John Lewer and Egbert Groen}

ABSTRACT: Boeing's maintenance workers at the Williamtown RAAF base in New South Wales went on strike during 2005-2006 in a campaign to achieve a collective agreement in the face of Boeing's determination to rely on individualbased industrial instruments. The dispute was one of the longest in Australia's recent history and ended with the defeat of the strike. Although Australia has ratified International Labour Organization Conventions on the right to bargain collectively, the dispute demonstrates the absence under the Workplace Relations Act 1996 (Cth) of any legal mechanism to resolve disputes over union recognition and, more broadly, the lack of genuine choice available to workers who seek to bargain collectively with an employer.

\section{Introduction}

Central to orderly industrial relations in any pluralist society is the right of workers to join unions and to bargain collectively; indeed, this is considered by the International Labour Organization (ILO) to be a fundamental human right. However, the enactment of the Workplace Relations Act 1996 (Cth) (WRA) by the Howard government and its interpretation in subsequent case law mean that no enforceable obligations now exist in the federal jurisdiction which require employers to bargain collectively. This makes Australia distinctive among developed nations.

These features of Australian labour law were graphically illustrated by the industrial dispute between Boeing Australia and a group of its employees at Williamtown (near Newcastle, New South Wales) in 2005-2006 and by related actions before the federal and NSW industrial relations tribunals. These employees, who were dissatisfied with their wages and working conditions, joined a union (the 
Australian Workers' Union, or AWU) and sought to negotiate a collective agreement with Boeing. The company refused to enter into collective negotiations and, as a corollary, to recognise the AWU, and insisted on the continuance of individual contracts. In the face of this refusal, and with no legal remedy available under the WRA, the employees took direct action with a strike. Unable to break Boeing's resolve, the employees were eventually forced to return to work 256 days later, with no collective agreement. Widely covered in the media, the dispute focused public debate over the industrial relations policies of the federal Liberal/National Coalition government (1996 to present). Ironically, eight months after the dispute ended, Boeing registered a non-union collective agreement which contained many of the substantive claims originally demanded by the striking employees.

This article explores the issues raised by the dispute in three main parts. First, it reviews the concepts of union recognition and the right to bargain collectively, and it outlines the key legal mechanisms designed to protect a right to bargain collectively in Australia and in countries comparable to Australia. The second part describes the dispute at Williamtown, including the background, the sequence of events, and a detailed analysis of the arguments used by Boeing's management to rationalise its position in the dispute. The third and final section summarises the main points and explores their implications for the present and future of industrial relations in Australia.

\section{Definitions and Legal Mechanisms}

The right to bargain collectively rests on two main concepts: the freedom of association and union recognition. The former is well articulated in Convention 87 of the ILO (ILO 1948, Article 2):

Workers and employers, without distinction, shall have the right to establish and, subject to the rules of the organisation concerned, to join organisations of their choosing without previous authorisation.

Under this Convention, countries that are members of the ILO and that ratify the Convention are obliged to 'take all necessary and appropriate measures to ensure that workers and employers may freely exercise the right to organise' (ILO 1948, article 11). In most cases, the collective organisations that workers join are unions.

Convention 98 of the ILO furthers the right to association by declaring that workers exercising this right should be protected from 'acts of anti-discrimination in respect of their employment', that 'workers' and employers' organisations shall enjoy protection against any acts of interference by each other', and in particular that workers' organisations should be independent and protected against domination by 
employers or employer associations (ILO 1949, Articles 1 and 2). This Convention goes on to declare that member countries who ratify the Convention should take action to implement its provisions (ILO 1949, Article 4):

Measures appropriate to national conditions shall be taken, where necessary, to encourage and promote the full development and utilisation of machinery for voluntary negotiation between employers or employers' associations and workers' organisations, with the view to the regulation of terms and conditions of employment by means of collective agreements.

The last declaration relates to union recognition. If workers are to exercise their right to bargain collectively, then their collective organisations (again, usually unions) must be 'recognised' by employers as the representatives of workers in negotiations over wages and working conditions. The President of the Australian Council of Trade Unions put the issues more colourfully by arguing that the right to join a union without the union being recognised for bargaining purposes was like 'being allowed to join a golf club, but not being able to play on the course' (cited in Barnes 2006: 371).

The necessity of union recognition, if the right to bargain collectively is to be exercised, leads to the question of what happens when employers refuse to recognise and bargain with unions? Different countries have addressed this issue in different ways, but it is rare indeed amongst the developed countries for a legal mechanism not to be established to resolve disputes over union recognition. The United States, Canada and Britain all provide opportunities for a union to demonstrate the support it enjoys amongst workers (sometimes through proof of union membership, sometimes through secret ballots to prove support) and, if the union is successful, then there is a legal obligation on the employer to negotiate with the union (see for example Briggs 2006; McArthur 2004; Wood and Godard 1999). Other countries, such as Japan, Korea, Luxembourg and Spain operate similar 'good faith bargaining' systems (Naughton 1995: 92-3), while in some countries, like Germany, trade unionism and the right to collective bargaining are enshrined in the constitution.

In Australia before 1993, and focusing mostly on the federal system, the legal mechanism for union recognition came (albeit indirectly) through the system of compulsory conciliation and arbitration. Once unions were registered under the relevant legislation, they gained the right to represent workers, according to the boundaries of union rules, within the system. Summarised very simply, if a registered union approached an employer seeking to negotiate wages and working conditions (regardless of whether they had any members employed by that employer) and the employer refused, the union could initiate proceedings before the industrial tribunals. Compulsory conciliation would then take place. 
Penalties were available for non-compliance. If the employer still refused to enter into meaningful negotiations or if the parties could not reach agreement, the tribunal would arbitrate, thereby creating an award. In essence, there was a strong incentive (if not a direct obligation) for employers to recognise unions because refusal would lead to compulsory arbitration.

From 1993 onwards, as the focus of the federal system moved towards collective bargaining rather than conciliation and arbitration, the treatment of union recognition changed. Briefly between 1993 and 1996, the federal Labor government introduced the concept of 'bargaining in good faith' (Naughton 1995). The intentions of this legislation seemed clear, but subsequent case law found the solution it offered to the recognition issue was less than perfect. Indeed, the outcomes of two key cases decided by the Full Bench of the Commission (namely, Asahi Diamond Industrial Australia Pty Ltd v. Automotive, Foods, Metals and Engineering Union (AIRC 1995) 59 IR 385; and Appeal by the Public Sector, Professional, Scientific, Technical, Communications, Aviation and Broadcasting Union (1994) AILR 372) produced a narrow definition of 'bargaining in good faith'. McCallum's assessment of the 1993 legislation seems accurate:

[T] he Keating Government and the trade union movement did not squarely face the issue of anti-union employers refusing to bargain with trade unions. More importantly they did not appreciate that trade union bargaining at the level of the employing undertaking was of a different juridical nature from obtaining award coverage through an industry-wide arbitrated settlement by the Federal Commission. (Cited in Briggs 2006: 12)

Ultimately, the difficulties encountered by the 'good faith' jurisdiction became 'academic' because it was repealed by the new federal Coalition government with the passing of the Workplace Relations Act in 1996 and its implementation in 1997. Not only was there no legal mechanism to directly resolve disputes over union recognition, but the new status given to statutory individual contracts (in the form of Australian Workplace Agreements, or AWAs) gave employers new opportunities to thwart workers seeking union representation and unions seeking to bargain collectively over wages and working conditions. In particular, by creating the new option of individual contracts and appearing to maintain neutrality over the choice between individual and collective agreements, the new laws actually allow an employer who prefers individual contracts to prevail over even a significant majority of employees who seek to bargain collectively (Riley 2000; Briggs 2006: 13-17). Indeed, there were a number of major disputes in Australia in the late 1990s in which large employers (including BHP, Telstra, the Commonwealth Bank, ANZ Bank, and Patrick) used individual contracts to undermine union attempts to negotiate collective agreements, if not to deny union recognition completely 
(Thornthwaite and Sheldon 2001). These disputes informed decisions by the ILO that found several aspects of the WRA to be in breach of Conventions 87 and 98 (Thornthwaite and Sheldon 2001: 17-19).

More recently, a key case interpreting the WRA came before a Full Bench of the Australian Industrial Relations Commission (AIRC) (constituted by the Commission President, Justice Giudice, Senior Deputy President Marsh and Commissioner Grainger) on an appeal from a decision of Commissioner Smith. Smith considered the changed regulatory arrangements introduced under the WRA in Community and Public Sector Union v. Sensis Pty Ltd (AIRC, PR927827, 2003) - a dispute over the type of agreement to be made and how negotiations were to be conducted. Commissioner Smith's decision had relied, inter alia, on section 3(e) of objects of the WRA, as it then was, but the Full Bench held that there was no duty on the parties to negotiate in good faith nor had any of the parties submitted that such a legal duty arose under the Act (AIRC 2003: paras 25-9):

There clearly is no such duty. Such a duty is known to United States labour law ... There are no equivalent provisions in the Workplace Relations Act 1996. The Commission is required, relevantly, to act according to equity and good conscience. It may be accepted that if registered organisations, employees or employers act other than in accordance with those precepts the Commission may take that fact into account when exercising its discretion. But that is a different matter entirely to the question of whether there is a legal duty to bargain in good faith.

Despite this unequivocal decision, the Full Bench held that a direction 'requiring an employer to attend a conference in the Commission or to meet with a union may be seen as appropriate'. They were not prepared to conclude that such an order would 'always be beyond jurisdiction' and that 'it would depend upon the circumstances, including the submission of the parties' (AIRC 2003: paras 34-5). In effect this meant that, subject in this case to the determination of Commissioner Smith on the evidence, representatives of the Community and Public Sector Union (CPSU) could still have a role in the negotiations with Sensis. Sensis then made an application to the High Court for prerogative relief which was remitted to the Federal Court of Australia (FCA) in July 2004. In Sensis Pty Ltd v. Members of the Full Bench of the Industrial Relations Commission (2005, FCAFC 74) the court (Justices Wilcox, French and Finkelstein) dismissed the application on the grounds that, in summary, the involvement of the CPSU would not deprive Sensis of making a non-union agreement under (former) section 170LK of the WRA should it so wish. Rather, the only effect of such a direction would be to provide union assistance to the employee representatives involved in the negotiations; a desire which: 
... does not seem unreasonable ... as they are confronted with management representatives that include a lawyer and the company's human resource manager. It is difficult to understand why any fair-minded employer would wish to deny expert assistance to an employees' negotiation team placed in that situation. (FCA 2005: para. 65)

Their Honours were satisfied that such an order did not confer an entitlement on the CPSU as a party to the negotiations in their own right. This resolved the tentative view expressed by the Full Bench in the appeal that the direction sought by the CPSU may go "beyond what might legitimately be directed because it tends to deprive the employer of its right to pursue its preferred form of agreement' (FCA 2005: para. 40).

Creighton and Stewart (2005: 221) have expressed the view that 'even within the constraints mentioned by the Full Bench in Sensis, an AIRC member might well be able to fashion orders that have the practical effect of requiring an employer to recognise a bargaining agent'. However, the judgment of the Federal Court plainly asserts that, at best, unions with members in the organisation can only assist the employee representatives. The rights of employers to choose their preferred form of agreement are unfettered. This is consistent as well with a decision of the Federal Court of Australia in Australian Workers' Union v. BHP Iron Ore Pty Ltd (2001) 106 FCR 482, which, as Owens and Riley (2007: 481) explain, 'makes clear that the freedom of association rights in Australian federal law from 1996 to 2005 did not support a right to collective bargaining'. This was the legal context in which the Boeing dispute was conducted.

\section{The Boeing Dispute at Williamtown}

The account of the dispute that follows draws on a range of data sources. A full bench of the Industrial Relations Commission of NSW (IRC) handed down a comprehensive report on the dispute in February 2006 (IRC 2006), and this provides a key reference point, due to the wide-ranging evidence given by witnesses under oath and the ready accessibility of the transcripts. As well, the final decision in the dispute by the Australian Industrial Relations Commission provides a useful summary of events (AIRC 2006). However, other sources include contemporary media reports, the union's website on the dispute, the transcripts and decisions of other tribunal hearings, and a small number of interviews with participants.

\section{Background}

Boeing is a large American multinational corporation that produces aeroplanes and engages in a range of design, manufacturing and service activities in the aerospace 
industry. It has a worldwide workforce of over 150000 employees (Boeing 2006) and has been associated with the Australian aerospace industry for over 75 years (Boeing Australia 2005a). In Australia the Boeing group of companies employs approximately 3300 people across twenty locations, primarily in the provision of aerospace and communications services (Boeing Australia 2005b; IRC 2006: paras 16-17). One of its divisions, Military Aerospace Support (MAS), employs almost 1000 people across six sites in Australia (IRC 2006: paras 16-17).

In November 1999, one of Boeing's Australian subsidiaries within MAS, Boeing Australia, won a contract from the Department of Defence (worth a reported $\$ 500$ million) to modify and maintain the 70-plus fleet of F/A18 Hornet jet fighters held by the Royal Australian Airforce (RAAF), Oakey. Its trade workforce totalled around 400 full-time employees who performed maintenance, modification and upgrade on a range of military aircraft across three work sites: Williamtown in New South Wales, and Amberley and Oakey in Queensland (Boeing Australia 2005b). According to Boeing management, workers regularly moved between these sites according to demand (AIRC 2005; ABC 2005).

Work on the Hornet contract began at Williamtown in 2000. The number of employees involved was a matter of some contention in the dispute (ABC 2005; AIRC 2005), but it seems there were about 90 highly skilled aviation trade employees (70 excluding apprentices) who worked on the Hornet contract, representing three trade areas: avionics, structures and mechanical maintenance engineering (AIRC 2006: para. 3; Boeing Australia 2005b). Until late 2004, the engineers either had no experience of unions or, despite any previous union membership, had not sought active union involvement on the site. It was only a failure to progress grievances with management in 2004 that brought these employees together with the union. In the words of one of the employees engaged in the dispute:

We started a bit of a match with the management, probably a year before we got the union in ... it took us a year to really realise we were absolutely getting nowhere on our own ... I don't think a single one of us wanted to get the union in there, but at the time they were just completely necessary. (Reeves cited in ABC 2005)

Within the Boeing group of companies in Australia there is variation in industrial relations arrangements at different sites, including both federal awards and federal certified collective agreements negotiated with various unions (IRC 2006: paras 24-7). However, within the MAS division of Boeing Australia, the IRC Inquiry identified a historical policy of 'dealing with employees on an individual basis' (IRC 2006: para. 29; Boeing Australia 2005b; ABC 2005). Certainly, from the beginning of the Hornet contract in 2000, all engineers at Boeing Williamtown were employed on individual contracts, initially AWAs under the Workplace Relations 
Act. Evidence presented to the IRC inquiry suggested a degree of dissatisfaction with these arrangements as early as October 2001, including dissatisfaction with individualised performance reviews and pay increases, and concerns about payment of above award wages, inadequate maintenance of classification relativities, and lack of management response to employee concerns (IRC 2006: paras 40-3). Indeed, documents from Boeing from this period were cited in the IRC inquiry report as explicitly recognising 'that "a number of employees are unhappy" and that "there is an issue of how the company responds to such issues and it does not always do this well"' (IRC 2006: para. 40).

In response to some of these concerns, it appears Boeing proposed a new individualised arrangement for employees (IRC 2006: para. 42). Around 2002, most accepted a management-initiated change to common law individual contracts, which gave workers what was called the Total Remuneration Package (TRP). That is, their wages were paid as an annual salary, with no penalty rates for overtime, public holidays, weekends or shift work (AWU 2005). A small number of workers declined the common law contracts and stayed on AWAs, believing that the wages plus penalty rates formula would be better for them in the long run (IRC 2006: paras $46-8$ ).

Discontent among some of the maintenance engineers continued and then began to intensify in the second half of 2004, initially around an increase in and uneven distribution of difficult work inside aircraft fuel tanks and the lack of an allowance to compensate those undertaking this work (Cadzow 2006: 23; IRC 2006: paras 50-7). From this base, further dissatisfaction grew about the lack of transparency in the payment system, perceptions of unfairness in the performance appraisal system, anomalies in the pay rates, and unhappiness over some aspects of working hours and lunchroom facilities (see IRC 2006: paras 58-63).

The engineers raised their grievances with management, without success. Indeed, the IRC found that (IRC 2006: para. 64):

... it is difficult to identify any action taken by Boeing to address or ameliorate these grievances and problems during this period. Boeing's attitude at this time was simply that the grievances lacked validity.

In late 2004, a number of the aggrieved maintenance workers turned to the union. In the words of one of the Hornet maintenance engineers:

... we wanted someone to help us talk to our employer ... we thought, 'how can we get together as a group and get them to listen?'. (Cited in Cadzow, 2006: 24)

The union in question was the Australian Workers' Union (AWU), which is one of Australia's oldest unions, and would be best described as a 'conglomerate' 
union, in that it recruits members from a wide range of occupations and industries, including aviation. Within manufacturing, its membership includes employees from industries as diverse as textiles, air-conditioning and engineering (AWU 2006). The AWU has a sub-branch based in Newcastle and officials from this branch began to target the local aviation industry, and specifically Boeing's Williamtown site, in October 2004, requesting permission to hold meetings with employees about the benefits of union membership (IRC 2006: para. 66). These were initially facilitated by the company. The union subsequently recruited a large number of the engineers at Williamtown: seventeen at the first out-of-hours meeting in December 2004, increasing to a peak in April 2005 of 45 to 48 engineers working on the Hornet contract.

\section{The progress of the dispute}

The solution to the engineers' problems proposed by the union was to negotiate a collective agreement. This suggestion was immediately and vehemently opposed by Boeing when first raised by the union just before Christmas 2004. Indeed, there was evidence from within management's ranks of Boeing's position a month or so earlier, when a senior Boeing manager (IRC 2006: para. 76):

... expressed hostility to the notion of any union becoming involved in the operations at Williamtown, and told us [the other managers] that we were not to do anything to encourage a union presence at the site.

After some further meetings between the union and Boeing management, the union notified the NSW Industrial Relations Commission of a dispute on 25 January 2005, but this was withdrawn after Boeing claimed that the workers in question were covered by the federal Metal Industries Award and therefore that the dispute fell within the federal jurisdiction. Boeing held some discussions with its employees, but refused to recognise the union as their representative and the respective positions of the employer and the unionised employees hardened. The union initiated a bargaining period with the AIRC on 3 March 2005 and took protected industrial action both on 21 April 2005 (in the form of a three-hour stoppage) and from 11 to 18 May 2005 (in the form of a ban on filling out time sheets). Boeing responded by refusing to pay these workers and, after some further procedural sparring, an indefinite strike by 35 AWU members began on 22 June 2005.

The strike went through many stages over the subsequent eight months before the remaining 25 employees returned to work on 20 February 2006. The union devoted considerable resources to the dispute, maintaining an extensive website and a continuous picket site outside the Williamtown plant - which became a focus for the broader union campaign against the new changes to federal workplace 
laws proposed by the federal Coalition government, and gained enormous media attention. More important for this article, the union made many attempts to use both federal and NSW labour laws to resolve the dispute, and thereby to gain recognition for the union as the representative of the employees. This was unambiguously a dispute about the issue of the right to bargain collectively - as the AIRC put it, the 'heart' of the dispute was the 'question of union recognition and bargaining rights' (AIRC 2006: para. 2).

The AWU's initial bargaining notice sought the assistance of the AIRC in negotiating a settlement and later the union notified two separate but related industrial disputes, on 23 May and 8 August 2005. Between March and November 2005, the AWU participated in conciliation proceedings at the Commission on six occasions (AIRC 2006: para. 8).

In September 2005, the union applied to the AIRC for an order requiring a secret ballot of Boeing's employees at Williamtown. Eventually, Senior Deputy President Marsh published a decision on 25 November 2005 granting the ballot, but the union and Boeing were unable to agree on balloting procedures and the ballot was never conducted (AIRC 2006: para. 9).

Further attempts at conciliation in the AIRC during November failed, and the AWU sought and gained the assistance of the NSW Labor government. On 4 November 2005, the NSW Industrial Relations Minister announced the establishment of an inquiry into the dispute by a Full Bench of the NSW Commission, which subsequently heard evidence on fifteen days between 16 November 2005 and 27 January 2006. The NSW Commission's report, which was released on 17 February 2006 , not only set out in great detail the facts of the case but also concluded that the dispute could be heard, and indeed resolved, within the NSW jurisdiction (IRC 2006). The AWU took the opportunity presented by the Commission's report to lodge a dispute with the NSW Commission and initial conciliation proceedings commenced on 21 February 2006. Embracing this face-saving device, the striking employees returned to work the following day.

Boeing, however, refused to accept these developments and applied to the AIRC for an order restraining the NSW Commission from dealing with the dispute. On 23 February 2006, a Full Bench of the AIRC handed down a decision granting Boeing's application, thereby confirming that the dispute lay within the federal jurisdiction (AIRC 2006). More important, the Full Bench acknowledged that it had no power to arbitrate the dispute, and thereby to grant union recognition:

It was submitted, at least inferentially if not directly, that we [the AIRC] should give way to the New South Wales Commission because it has the power to arbitrate whereas this Commission does not. Accepting for the purposes of argument that this Commission has no arbitral capacity in the circumstances 
of the dispute, that is the nature of the scheme enacted by the Commonwealth Parliament and which this Commission is statutorily bound to follow... It may also be true that there is no statutory or other machinery for according recognition to unions at the enterprise level, nor any duty on employers to bargain collectively, but that is the system which the Australian Parliament has decided should apply. (AIRC 2006: paras 46 and 47)

\section{Boeing management's position}

Given the extraordinary length of the dispute, the disruption it created, the costs it imposed on all parties, and the enormous media and political attention it aroused, it is important to understand as best as possible the motivation and rationale behind management's position in the dispute. This is not an easy task because Boeing managers were unavailable for interview and rarely made public statements about the dispute. The following account comes from a patchwork of sources.

The Boeing position from the beginning of the dispute was not to oppose their employees' right to join the union, but rather to deny the union the opportunity to negotiate on behalf of its members. This position was summarised in a letter to the union from the Managing Director, dated 22 March 2005, saying (cited in IRC 2006: para. 90):

Discussions about remuneration issues, including salary reviews, are addressed on an individual basis. Boeing does not favour a collective approach to wage negotiation, because that approach does not fit with our business objectives.

I recognise that there are different approaches to these issues, and I also take on face value your union's advice that some of our employees are dissatisfied with this approach to our relationship with them ... [But] I am not convinced that there is any advantage to Boeing or to its workforce in moving away from the current arrangements.

Similarly, as late as November 2005 came the statement:

Boeing does not believe it should be forced to change employment arrangements which have been in place successfully for many years simply because the AWU is demanding a collective rather than an individual arrangement. (Boeing Australia 2005b)

Central to this position was an argument that the individual contracts that had operated since 2000 had served the interests of Boeing well and had been 
accepted by the vast majority of Boeing employees (ABC 2005). On the former, the NSW Commission (2006: para. 155) placed the arguments put forward by management into four categories:

1. a collective agreement did not fit with Boeing's 'business objectives';

2. Boeing did not wish to take the risk of adopting a new, untried model;

3. individual contracts best delivered the 'seamless' mode of employment required to manage labour across Boeing's three sites; and

4. management preferred to deal with its employees on an individual basis.

Having so categorised management's arguments, the IRC subsequently reviewed the validity of each against the evidence and found them seriously wanting (IRC 2006: paras 157-9). The Commission found that management was extremely vague in defining its 'business objectives' and, despite repeated questioning, was unable to explain why these objectives could only be met with individual contracts. Given the effective operation of collective agreements in other Boeing subsidiaries in Australia and the evident problems encountered with the system of individual contracts at Williamtown, it was not obvious to the Commission why collective agreements were so risky (IRC 2006: para. 159). It was also not at all clear why the movement of employees across sites (which was the main feature of the company's desired 'seamless' mode of employment) could not be achieved successfully with a collective agreement (IRC 2006: paras 160-1). Finally, despite the company's rhetoric about individual treatment of employees, the evidence was that the company actually did not negotiate with individual employees - rather, it offered uniform, 'stock standard' contracts to all its employees. Consequently, its opposition to collective bargaining appeared to be based more on a desire to maintain managerial prerogative rather than genuine individual bargaining with employees (IRC 2006: paras 162-70). It is worth quoting at length the IRC's assessment of the last of management's arguments:

Therefore, we consider the fourth reason advanced by Boeing to justify its position is properly characterised as one whereby it wishes to avoid, as far as possible, any context in which it is required to engage in negotiations about the terms and conditions of employment of its employees, and to limit the capacity of its employees to be represented in such negotiations by a union. We accept that this approach, from the point of view of Boeing's selfinterest, provides a rational basis for Boeing's refusal to enter negotiations for a collective agreement. The system of individual contracts which it has established is one, however, which entrenches an inequality in economic and workplace power between Boeing and each of its employees at Williamtown, and thereby maximises Boeing's discretionary capacity to set and change 
terms and conditions of employment to suit its own interests. A departure from that system to one of collective bargaining with a union would, for Boeing, carry the risk of diminishing this inequality of power or limiting or removing Boeing's discretionary capacity. (IRC 2006: para. 168)

Some of management's actions, rather than their words, also demonstrate how the system of individual contracts operated at Williamtown and, correspondingly, why management might oppose collective bargaining. In February and March 2005 , in the period immediately after the union aired the grievances of its members and made its demands for a collective agreement, management conceded that communication with employees over their concerns had been less than adequate and needed to be improved (IRC 2006: para. 90-4). Consultation with its employees, ostensibly to gain feedback on how the payment system under the individual contracts should be improved, was initiated at the same time as the AWU and its members began to engage in protected industrial action (IRC 2006). This consultation was through a 'focus group' of employees, brought together by management (rather than elected by employees). AWU delegates did attend the focus group, but AWU officials were not permitted to participate in the process (IRC 2006: paras 101-12; AIRC 2006).

The focus groups generated not only a shift in management's position on wages and conditions for its employees (with a proposed package of improvements to the remuneration system for all employees across the three sites in the form of revised offers to individual contracts) but also appeared to entrench Boeing's refusal to negotiate a collective agreement, with or without union involvement (IRC 2006: para. 114). It also appears that management was conscious of employee retention in a tightening labour market, with significant skill shortages being common and evidence that remuneration levels at Boeing were significantly lower than at a number of its competitors (IRC 2006: paras 107-8). Interestingly, Boeing management was also aware of the risk that unions could claim the credit for the improved remuneration; in management's words: 'other disaffected groups of employees may see joining a Union has resulted in resolution of issues for Trades employees and consider the same course of action' (IRC 2006: para. 107).

On the second point - the argument that collective bargaining with the union was unnecessary because individual contracts had been overwhelmingly accepted by the vast majority of Boeing employees - the senior manager on the Williamtown site told the $\mathrm{ABC}$ (2005):

I think it's important to understand that $90 \%$ of the workforce are aircraft maintenance engineers across our three sites. That's Williamtown, Amberley and Oakey. They've made a choice, and that choice has been to remain on their current individual contracts, or individual arrangements. At Williamtown 
we have 25 of our own employees, and that represents less than a third of our aircraft maintenance engineers at Williamtown, and less than $7 \%$ across Boeing Australia, who are pursuing a collective agreement, a collective arrangement through the AWU ... And when put into context with the fact that $92 \%$ of our workforce have chosen to stay on the current arrangements, that makes a very compelling argument.

This statement reveals at least two key points about Boeing's position. The first concerns the competing definitions of the 'bargaining unit': management considered all employees across its three sites as the main issue, while the union sought a collective agreement to cover only the maintenance engineers at Williamtown. In this way, management was able to marginalise the number and importance of the striking workers who were seeking a collective agreement, while the union's narrower definition of the group involved (the 70 to 80 maintenance engineers at Williamtown) maximised their importance.

Second, management considered that by signing individual contracts, rather than joining the strikers, other employees at Williamtown and at the other sites were 'choosing' individual contracts over a collective agreement and thereby supporting management's position. This is a highly idiosyncratic definition of 'choice' and very different to the test of choice embedded in the legal systems of many other countries, where employees are given the opportunity to vote in a secret ballot over whether they support a union and collective bargaining. The peculiarities of this position were reinforced later in the dispute, when the AWU approached the AIRC seeking a ballot of Boeing employees to determine their preferred bargaining forms, and Boeing management rejected the idea.

Until the end of the dispute, Boeing continued to argue that a key element in its opposition to union recognition and to negotiating with the union over a collective agreement was a preference for individual arrangements with employees.

\section{The non-union collective agreement}

In late October 2006, Boeing announced that it had negotiated a non-union collective agreement covering more than 500 employees across its three defence sites. Apparently, after the return of the striking workers, the company had again consulted with its workforce through focus groups, without union involvement. The resulting collective agreement had been accepted in a ballot by 94 per cent of employees (Newcastle Herald 2006).

Boeing management were reported to be 'pleased with the outcome', saying that 'this is a great result and shows what can be achieved when employers and employees sit down and are prepared to negotiate fairly and without any pre- 
conditions' (Newcastle Herald 2006). No explanation was offered for the collective (as opposed to individual) nature of the agreement, although media sources speculated that high turnover and a dwindling workforce were a contributing concern (Workplace Info 2006). In a curious twist, a spokesperson for Boeing is reported as saying the company had always been willing to negotiate collectively but could not agree to the terms put forward by the workers and the AWU (Workplace Info 2006). The union's 'unworkable' collective agreement had instead been replaced by employees negotiating a 'sensible' contract (Workplace Info 2006).

The AWU released a press statement welcoming the improved employment conditions contained in the collective agreement, claiming that they proved the previously poor conditions at Boeing as compared to the rest of the industry and claiming that eight of the eleven claims made by the striking employees had been included in the new agreement (AWU 2006). The union also argued that its interests had actually been represented in the focus groups by the participation of one of its striking members and that the collective nature of the agreement demonstrated the inappropriateness of individual contracts.

\section{Discussion and Conclusion}

The long-running Boeing dispute at Williamtown focuses a spotlight on the nature of collective bargaining rights and the (emasculated) role of trade unions operating under the Workplace Relations Act 1996 (Cth) - rights that can only be more deeply wounded by the operation of the WorkChoices amendments to the Workplace Relations Act introduced by the federal Coalition government. In particular, the dispute vividly demonstrates the absence of a legal mechanism to peacefully resolve disputes over union recognition. A group of employees, working under individual contracts with grievances over substantive terms of employment and frustrated by their employer's refusal to address their grievances, was forced to strike in pursuit of a collective agreement because there was no legal alternative. The strike lasted many months and imposed significant costs on employees as well as unions and employers. It gained widespread public attention and became the subject of an extensive inquiry by the NSW IRC. And yet the employees were eventually defeated by a determined and powerful employer - a large American transnational corporation.

In contrast to previous labour law regimes in Australia, the AIRC was unable to arbitrate the dispute. Indeed, the Boeing dispute serves as a reminder of the severely restricted role of the AIRC under the Workplace Relations Act to resolve industrial disputes either by the notification of one of the parties or by the Commission itself on its own motion. The NSW Commission retains the power to 
arbitrate, and could conceivably have resolved the dispute, but the decision of the Full Bench of the AIRC headed by the President Justice Giudice at the end of the dispute dismissed any role for the state tribunal (AIRC 2006). The expansion of the federal jurisdiction delivered by the WorkChoices amendments further reduces the prospect of state systems providing effective alternatives for union recognition.

The same Full Bench of the AIRC explicitly acknowledged the lack of any 'statutory or other machinery for according recognition to unions at the enterprise level', reminding the parties that such law was the result of legislation passed by Parliament (AIRC 2006: para. 47). The same point was made by Prime Minister Howard when he noted in Parliament that:

And so far as the entitlements are concerned to negotiating a collective agreement, the existing law means that the company [Boeing] is within its rights taking the position it is. It is fair and proper under the existing law, $\mathrm{Mr}$. Speaker. I understand that the 31 employees can go back to work on their old terms or accept new terms that would see every one of them get a pay rise Mr. Speaker. It is their choice. (Cited in ABC 2005)

This reveals the true nature of 'choice' under the WRA. An 'agreement', whether individual or collective, is voluntary for both sides. As then Minister Andrews put it, again referring to the Boeing dispute (ABC 2005):

Well, the nature of agreement is what the word suggests, it's an agreement. It's an agreement by both the employers and the employees. And in this case, if the employer doesn't wish to have a collective agreement, wants to continue essentially what are individual common law arrangements, then the employer's entitled to do that, there's no change in what we're proposing from what the current situation is.

As the NSW Commission pointed out, however, support for the 'voluntary' nature of agreement-making ignores the significant inequalities in the labour market and in the workplace between employers and workers. The choices available to workers in situations like those at Boeing Williamtown are threefold: go on strike until the employer concedes (although the ever increasing restrictions imposed on union industrial action make success in such a venture less likely); accept the employer's bargaining preference; or leave and find another job. The following exchange between a journalist and Minister Andrews (ABC 2005) confirms this analysis:

ANDREWS: Look I understand what they're [workers at Boeing] saying, but the reality is in their words, their words, which are used: 'There are other jobs we can go to if we don't like working on this job', but they're making a choice that they want to work on this particular job; the company is saying 
'Well, working on this particular job involves this particular instrument of employment. We're happy to have you.' But the choice ultimately is theirs $\ldots$

JOURNALIST: So effectively what you're saying is if workers want a collective agreement with an employer, the employer says 'No, we don't want to negotiate with them', they should get on their bikes.

ANDREWS: What I'm saying is an agreement is an agreement, which means both parties have to agree to it.

Finally, the dispute made clear the consistency of the Workplace Relations Act with the liberal theory of freedom of association. This maintains that an individual is a rational, free and independent being possessed of the positive freedom to associate and the negative freedom not to associate; a right, though, that does not extend to acting collectively. Some labour law scholars have argued that without the freedom to act collectively, freedom of association becomes a meaningless sham (see, for example, Owens and Riley 2007). Boeing could not oppose their employees' right to join the union nor to allow access to the work site to the AWU, but it was able to absolutely deny the union the opportunity to negotiate on behalf of its members. Boeing's ultimate decision to negotiate a non-union collective agreement also shows how the Workplace Relations Act marginalises unions, despite the AWU's claims that the union had some presence at the bargaining table through its members. As Owens and Riley claim, without trade union recognition rights in bargaining, their exclusion reinforces that (2007: 491):

Trade unions are simply out of place in the new economy: not only do they have no direct interest in work relations, being at most third-party interveners, but also their collectivist tradition marks them as anti-competitive cartels, hostile to the values of the market.

There seems little doubt, given the current state of federal labour law, as demonstrated by the Boeing dispute and in the case law reviewed in this paper, that the right to bargain collectively will remain a matter of controversy in Australian industrial relations. Certainly, a key part of the ACTU's (2006) Industrial Relations Legislation Policy is the right to collective bargaining through a system of 'good faith' bargaining, as is also true for the ALP's (2007) Forward with Fairness policy. While the details of implementation will be important should the ALP win government, such an approach would at least align Australian labour law with its obligations under the ILO's Conventions. 


\section{References}

ABC [Australian Broadcasting Corporation] (2005) 'Testing Industrial Relations', Background Briefing, Radio National, 23 October, available at $<w w w . a b c . n e t$. $\mathrm{au} / \mathrm{rn} /$ talks/bbing/stories/s1485849.htm $>$.

ACTU [Australian Council of Trade Unions] (2006) Industrial Relations Legislation Policy, available at <www.actu.asn.au>, accessed 3 September 2007.

AIRC [Australian Industrial Relations Commission] (1995) Asahi Diamond Industrial Australia Pty Ltd v. Automotive, Foods, Metals and Engineering Union (1995) 59 IR 385; and Appeal by the Public sector, Professional, Scientific, Technical, Communications, Aviation and Broadcasting Union (1994) AILR 372.

AIRC [Australian Industrial Relations Commission] (2003) Community and Public Sector Union v. Sensis Pty Ltd [PR927827], 17 February.

AIRC [Australian Industrial Relations Commission] (2005) The Australian Workers' Union v. Boeing Australia Limited, s.170MI, notice of initiation of bargaining period, BP2005/38, transcript of proceedings, 18 October.

AIRC [Australian Industrial Relations Commission] (2006) Boeing Australia Ltd v. the Australian Workers' Union [PR968945], 23 February.

ALP [Australian Labor Party] (2007) Forward with Fairness, available at <www.alp. org.au>, accessed 3 September 2007.

AWU [Australian Workers' Union] (2005) Information Brief to members, 7 April, available from <www.williamtown.org.au $>$.

AWU [Australian Workers' Union] (2006) Collective Agreement Always was the Preferred Option, press release, 27 October.

Barnes, A (2006) 'Trade unionism in 2005', Journal of Industrial Relations, 48(3), pp. 369-83.

Boeing Australia (2005a) official website, available at <www.boeing.com.au/BAL/ flash.html>, accessed November 2005.

Boeing Australia (2005b) Boeing Australia background facts, email correspondence from Boeing PR consultant, 24 November.

Boeing (2006) official website, available at <www.boeing.com>.

Briggs, C (2006) Statutory Union Recognition in North America and the UK: Lessons for Australia?, Workplace Research Centre, University of Sydney.

Cadzow, J (2006) ‘Strike Force’, Sydney Morning Herald, 27 May, pp. 21-6.

Creighton, B and Stewart, A (2005) Labour Law 4th edition, The Federation Press, Annandale.

FCA [Federal Court of Australia] (2005) In Sensis Pty Ltd v. Members of the Full Bench of the Industrial Relations Commission.

IRC [Industrial Relations Commission of New South Wales] (2006) Inquiry into the Boeing Dispute at Williamtown, Matter No. 5639 of 2005, 17 February.

ILO [International Labour Organization] (1948) Freedom of Association and 
Protection of the Right to Organize Convention, No. 87.

ILO [International Labour Organization] (1949) Right to Organize and Collective Bargaining Convention, No. 98.

McArthur, B (2004) 'The Efficacy of Statutory Union Recognition under New Labour: A Comparative Review' International Journal of Comparative Labour Law and Industrial Relations, 20(3), pp. 399-421.

Naughton, R (1995) 'Bargaining in Good Faith' in P Ronfeldt and R McCallum (eds) Enterprise Bargaining, Trade Unions and the Law, Federation Press, Sydney.

Newcastle Herald (2006) 'Boeing, workers agree on new deal', 27 October.

Owens, R and Riley, J (2007) The Law of Work, Oxford University Press, South Melbourne.

Riley, J (2000) 'Individual Contracting and Collective Bargaining in the Balance', Australian Journal of Labour Law, 13(1), pp. 92-9.

Thornthwaite, L and Sheldon, P (2001) 'Employer Matters in 1999', Journal of Industrial Relations, 42(1), pp. 83-108.

Wood, S and Godard, J (1999) 'The Statutory Recognition Procedure in the Employment Relations Bill: A Comparative Analysis', British Journal of Industrial Relations, 37(2), pp. 203-45.

Workplace Info (2006) 'Skills shortage forces Boeing to accept collective agreement', available from $<0$-www.workplaceinfo.com.au.library.newcastle.edu.au/ registered/alert/2006/061017923.htm>.

\section{JENNY WHITTARD, MARK BRAY, ROSLYN LARKIN,} JOHN LEWER AND EGBERT GROEN - Faculty of Business and Law, University of Newcastle 